\title{
Perencanaan Tebal Overlay dengan Alat Benkelman Beam dan Falling Weight Deflectometer
}

\author{
${ }^{1}$ Amir Mukhlis, Agustiar ${ }^{2}$ \\ ${ }^{1}$ Program Studi Teknik Sipil, Fakultas Teknik, Universitas Iskandar Muda \\ ${ }^{2}$ Program Studi Teknik Sipil, Fakultas Teknik, Universitas Muhammadiyah Aceh \\ 1amirmukhlis@hotmail.com, 2agustiar@unmuha.ac.id
}

\begin{abstract}
In a certain period, the road pavement will be damaged so this pavement needs to be overlay. There is pavement damage that needs overlay activity in the highway, so the pavement is needed to maintain. This study is performed to find the overlay thick of pavement (overlay) by using Falling Weight Deflectometer (FWD) and Benkelman Beam $(B B)$ tools. Overlay thick design is based on Design of Overlay Thick of Flexible Pavement by Deflection Method (Pd T-05-2005-B). The segment of this study is in Jalan Banda Aceh - Medan highway, the data that taken is from the same point between Falling Weight Deflectometer (FWD) and Benkelman Beam (BB). To design the thickness, this investigation needs the result deflection of Falling Weight Deflectometer (FWD) and Benkelman Beam (BB), then the value result is corrected. After the obtain corrected deflection value, the next process is calculating uniformty factor $(F K)$, representative deflection $\left(D_{\text {sbl ov }}\right)$, design deflection $\left(D_{\text {stl ov }}\right)$, overlay thick $\left(H_{0}\right)$, factor of overlay thickness $\left(F_{o}\right)$, and corrected overlay thick $\left(H_{T}\right)$. The result of this study is the overlay thick from Falling Weight Deflectometer (FWD) and Benkelman Beam (BB), it is 5,235 cm for Falling Weight Deflectometer (FWD) and 3,722 $\mathrm{cm}$ for Benkelman Beam (BB). The result difference between Falling Weight Deflectometer (FWD) and Benkelman Beam $(B B)$ is $1.513 \mathrm{~cm}$ or $28.90 \%$ in the percentage.
\end{abstract}

Keywords: Design, Overlay, Laston, Flexible Pavement

\begin{abstract}
Abstrak
Pada kurun periode tertentu, perkerasan jalan akan rusak sehingga perkerasan ini perlu dilapisi ulang. Saat ini, terdapat kerusakan perkerasan jalan yang membutuhkan pekerjaan lapis tambah pada jalan tersebut sehingga perkerasannya perlu dilakukan pemeliharaan. Penelitian ini dilakukan dengan mencari nilai tebal lapis tambah perkerasan (overlay) dengan menggunakan alat Falling Weight Deflectometer (FWD) dan Benkelman Beam (BB). Perencanaan tebal lapis tambah berdasarkan Perencanaan Tebal Lapis Tambah Perkerasan Lentur dengan Metoda Lendutan (Pd T-05-2005-B). Segmen dari penelitian ini adalah di Jalan Banda Aceh-Medan, data yang diambil adalah dari titik yang sama antara Falling Weight Deflectometer (FWD) dan Benkelman Beam (BB). Untuk merencanakan tebal nya, kajian ini membutuhan lendutan hasil pengujian dari Falling Weight Deflectometer (FWD) dan Benkelman Beam (BB), kemudian hasilnya dikoreksi. Setelah mendapatkan hasil lendutan terkoreksi, proses selanjutnya adalah menghitung faktor keseragaman $(F K)$, lendutan wakil $\left(D_{\text {sbl ov }}\right)$, lendutan rencana $\left(D_{\text {stl ov }}\right)$, tebal overlay $\left(\mathrm{H}_{\mathrm{o}}\right)$, faktor ketebalan lapis tambah $\left(\mathrm{F}_{\mathrm{O}}\right)$, dan ketebalan lapis tambah terkoreksi $\left(\mathrm{H}_{\mathrm{T}}\right)$. Hasil dari penelitian ini adalah tebal lapis tambah perkerasan dari Falling Weight Deflectometer (FWD) dan Benkelman Beam (BB), ketebalan yang didapat adalah 5,235 cm untuk Falling Weight Deflectometer (FWD) dan 3,722 cm untuk Benkelman Beam (BB). Selisih yang dihasilkan dari Falling Weight Deflectometer (FWD) dan Benkelman Beam (BB) adalah $1,513 \mathrm{~cm}$ atau sebesar $28,90 \%$ dalam bentuk persentase.
\end{abstract}

Kata kunci: Perencanaan, Overlay, Laston, Perkerasan Lentur. 


\section{Pendahuluan}

Penelitian ini bertujuan untuk mencari hasil perencanaan tebal perkerasan jalan dengan menggunakan alat Benkelman Beam (BB) dan alat Falling Weight Deflectometer (FWD). Dalam masa tertentu, perkerasan jalan mengalami kerusakan, seperti pada bangunan lain yang direncanakan untuk menerima beban rencananya namun tidak mengalami gaya tegang dan perpindahan [1]. Kerusakan ini disebabkan oleh akibat penurunan kapasitasnya. Selain itu, juga dapat terjadi peningkatan beban lalu lintas yang bekerja di atasnya.

Dengan arus lalu lintas yang cukup tinggi, maka mengakibatkan pengurangan umur sisa jalan. Selain itu juga dapat mengurangi kapasitas dari perkerasan jalan sehingga perlu dilakukan perawatan dengan menyediakan biaya yang diperlukan untuk perawatan tersebut.

Perawatan atau overlay dilaksanakan dengan melakukan perbaikan struktur perkerasan dengan memberikan lapis perkerasan yang baru. Dalam pelaksanaannya perlu diukur nilai lendutannya dengan menggunakan alat.

Pada perkerasan lentur, ada berbagai alat yang digunakan untuk memperoleh nilai lendutan tersebut, di antaranya adalah alat Benkelman Beam (BB) dan alat Falling Weight Deflectometer (FWD). Penggunaan alat ini berdasarkan metode perencanaan dan alat yang tersedia.

Pada dasarnya, kedua alat ini memiliki hasil masing-masing dengan metode perhitungan yang berbeda. Dengan demikian perlu dilaksanakan kajian mengenai perbedaan hasil perencanaan dengan kedua alat. Pada kajian ini, akan digunakan pengukuran lendutan dengan keduanya dan dilakukan penentuan tebal perkerasan overlay berdasarkan hasil alat yang digunakan

\section{Tinjauan Pustaka}

\subsection{Desain Tebal Overlay}

Desain tebal overlay atau lapis tambah perkerasan adalah desain untuk merekonstruksi perkerasan yang sebelumnya dibangun yang mengalami kerusakan struktural
[4]. Proses perbaikan ini perlu dilakukan oleh karena beban lalu lintas yang bekerja secara normal sudah tidak mampu ditahan oleh perkerasan tersebut. Dengan dilakukannya pelapisan ulang, maka kapasitas perkerasan akan membaik kembali sehingga dapat menerima beban pada kondisi normalnya [11].

Pendekatan yang digunakan pada penentuan tebal overlay menggunakan dua hal, yaitu berdasarkan deformasi permanen yang menggunakan nilai lendutan tertingginya, dan retak lelah yang menggunakan lengkung lendutannya [8].

Peninjauan terhadap kinerja lelah terhadap lapisan perkerasan yang perlu dilapisi ulang untuk perkerasan yang bersangkutan menggunakan nilai 100.000 ESA4, untuk nilai yang lain dapat menggunakan nilai yang lebih tinggi dari nilai ini. Tebal lapisan ulang perkerasan memakai pendekatan terhadap nilai lendutan maksimumnya $\left(D_{0}\right)$. Nilai tebal overlay diperoleh dengan menggunakan nilai lengkung lendutan serta rentang beban lalu lintas. Rentang beban ini digunakan pada kondisi iklim tropis pada saat kemarau.

Pengukuran nilai lendutan dapat menggunakan berbagai alat, salah satunya adalah alat Benkelman Beam (BB) dan alat Falling Weight Deflectometer (FWD). Alat Benkelman Beam (BB) ialah alat yang digunakan untuk mengukur lendutan berdasarkan dari hasil lendutan balik. Alat Falling Weight Deflectometer (FWD) ialah alat yang digunakan untuk mengukur lendutan berdasarkan lendutan yang diperoleh dari pusat beban [10].

\subsection{Alat Benkelman Beam}

Alat Benkelman Beam (BB) dirangkai dengan membuat hubungan dengan truk. Beban yang akan dipakai pada pengujian ditempatkan di bak truk yang mempunyai berat kosong sebesar 5 ton. Beban ditempatkan pada sumbu ban belakang dengan nilai beban 4,08 ton. Skema alat Benkelman Beam (BB) [9] dapat dilihat pada Gambar 1 di bawah ini: 


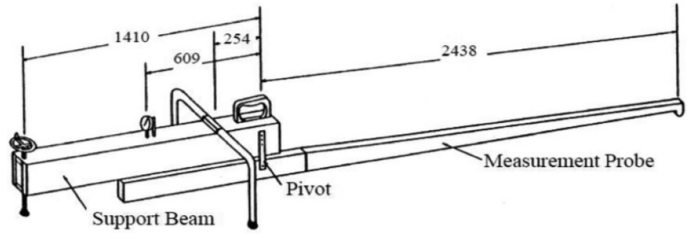

Gambar 1. Skema alat BB

Komponen alat BB adalah komponen batang pengukur, dan komponen kerangka dasar. Batang pengukur terdiri dari tumit batang dan kontak tumitnya, kaki depan dan pengunci. Pada tumit batang, terdapat kontak dengan permukaan jalan.

Dengan menggunakan alat BB, akan diperoleh nilai lendutan [6]. Lendutan ini adalah lendutan balik maksimum. Nilai lendutan balik maksimum ini diperoleh dari meteran dari beban yang bekerja pada alat. Lendutan dihasilkan dari getaran yang diberikan pada alat BB.

Nilai lendutan balik $\left(d_{B}\right)$ menggunakan persamaan di bawah ini.

$$
\mathrm{d}_{\mathrm{B}}=2\left(\mathrm{~d}_{3}-\mathrm{d}_{1}\right) \times \mathrm{F}_{\mathrm{t}} \times \mathrm{C}_{\mathrm{a}} \times \mathrm{FK}_{\mathrm{B}-\mathrm{BB}}
$$

Faktor koreksi lendutan pada alat BB menggunakan persamaan 2 .

$$
\mathrm{FK}=77,343 \times(\text { Beban Uji) })^{(-2,0715)}
$$

Beban uji yang digunakan 2 adalah ton.

\subsection{Alat Falling Weight Deflectometer}

Alat FWD mengukur lendutan dengan beban dinamik berupa impuls [7], disambung dengan dari trailer yang letaknya di belakang dari kendaraan penarik, pada kendaraan, terdapat prosesor dan komputer. Trailer memiliki beban uji yang berfungsi dengan menjatuhkan massa yang menghasilkan beban.

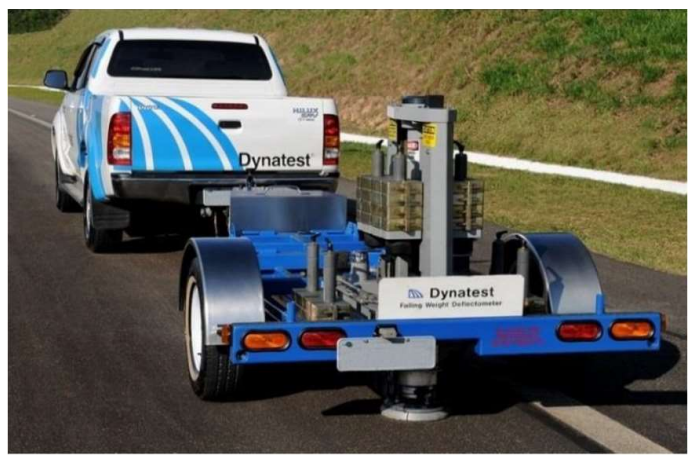

Gambar 2. Penempatan Alat FWD
Kemudian beban dibaca dengan perangkat pembaca sehingga dapat menghasilkan nilai berdasarkan impuls lendutan yang bekerja. Penempatan alat Falling Weight Deflectometer [5] dapat dilihat pada gambar 2 .

Nilai yang diperoleh dari alat FWD adalah nilai lendutan langsung [8]. Lendutan langsung (nilai $\mathrm{d}_{\mathrm{L}}$ ) menggunakan persamaan 3 :

$$
\mathrm{d}_{\mathrm{L}} \quad=\mathrm{d}_{\mathrm{f} 1} \times \mathrm{F}_{\mathrm{t}} \times \mathrm{C}_{\mathrm{a}} \times \mathrm{FK}_{\mathrm{B}-\mathrm{FWD}}
$$

Faktor koreksi lendutan pada alat FWD menggunakan persamaan 4 .

$$
\mathrm{FK} \quad=4,08 \times(\text { Beban Uji) })^{(-1)}
$$

Beban uji alat FWD yang digunakan pada persamaan 2 adalah ton.

\subsection{Tingkat Keseragaman Lendutan}

Tingkat keseragaman lendutan menggunakan persamaan keseragaman lendutan (FK).

$$
\mathrm{FK}=\frac{s}{d_{R}} \times 100 \%
$$

\subsection{Lendutan Wakil}

Lendutan wakil diperoleh dari persamaan lendutan wakil (untuk jalan Arteri), yaitu:

$$
D_{\text {wakil }} \text { atau } D_{\text {sbl ov }}=d_{R}+2 s
$$

\subsection{Lendutan Rencana}

Lendutan rencana atau disebut juga lendutan ijin didapat berdasarkan persamaan lendutan rencana:

$$
\begin{aligned}
\text { Drencana }_{\text {atau }} \mathrm{D}_{\text {stl ov }} \\
=17,004 \times \mathrm{CESA}^{-0,2307}
\end{aligned}
$$

\subsection{Tebal lapis tambah}

Tebal lapis tambah, diperoleh dari persamaan tebal lapis tambah atau overlay:

$$
\begin{aligned}
H_{\circ}= & \left\{\operatorname{Ln}(1,0364)+\operatorname{Ln}\left(D_{\text {sbl ov }}\right)\right. \\
& \left.-\operatorname{LN}\left(D_{\text {stt ov }}\right)\right\} / 0,0597
\end{aligned}
$$

\subsection{Faktor Koreksi Tebal Lapis Tambah}

Dengan menggunakan Temperatur perkerasan rata-rata tahunan (TPRT), faktor koreksi tebal lapis tambah $\left(F_{\circ}\right)$, didapat:

$$
\text { F。 } \quad=0,5032 \times \operatorname{EXP}(0,0194 \times \text { TPRT })
$$




\subsection{Lapis Tambah Terkoreksi}

Tebal lapis tambah terkoreksi diperoleh dengan menggunakan persamaan tebal lapis tambah terkoreksi $\left(\mathrm{H}_{\mathrm{t}}\right)$ :

$$
\mathrm{H}_{\mathrm{t}} \quad=\mathrm{H}_{\mathrm{o}} \times \mathrm{F}_{\mathrm{o}}
$$

\section{Metode Penelitian}

\subsection{Data Penelitian}

Data yang diambil pada kajian ini adalah data yang digunakan pada Jalan Banda AcehMedan dengan lokasi sepanjang 2 kilometer. Dari ruas jalan ini, ditentukan 5 titik yang dipakai sebagai pengambilan data $\left(n_{s}\right)$. Umur rencana yang digunakan pada lalu lintas lajur rencana ini adalah 5 tahun (CESA). Untuk tebal lapis beraspal yang digunakan adalah tebal 9 $\mathrm{cm}$. Untuk pengujian lendutan, data yang digunakan pada ruas jalan yang dikaji adalah data dengan menggunakan alat BB dan FWD. Untuk nilai koreksi musim yang digunakan $\left(\mathrm{C}_{\mathrm{a}}\right)$ yang dilaksanakan untuk musim kemarau sehingga nilai yang digunakan adalah 1,2.

\subsection{Prosedur Pengumpulan Data}

Untuk pengumpulan data, digunakan data untuk lendutan hasil pengujian di lapangan dengan menggunakan kedua alat, yaitu alat BB dan alat FWD. Pengambilan data dilaksanakan melalui uji beban menggunakan truk dengan menggunakan roda belakang ban ganda. Ban menggunakan tekanan angin 80 Psi dan dilakukan pengecekan di setiap 4 jam. Sketsa pengujian alat FWD [2] dapat dilihat pada Gambar 3.

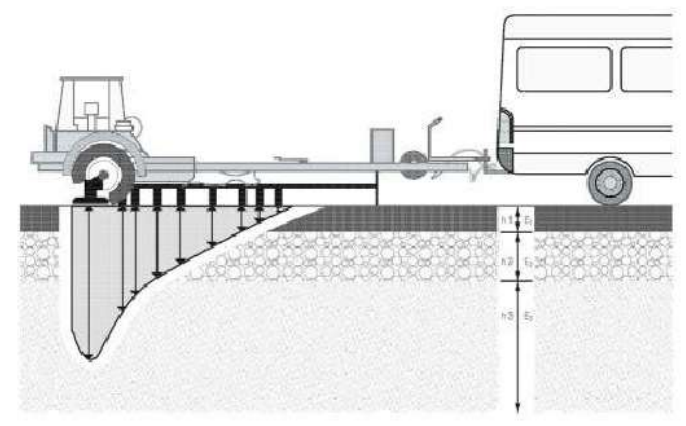

Gambar 3. Sketsa Pengujian alat FWD

Sketsa pengujian alat BB [3] dapat dilihat pada Gambar 4.
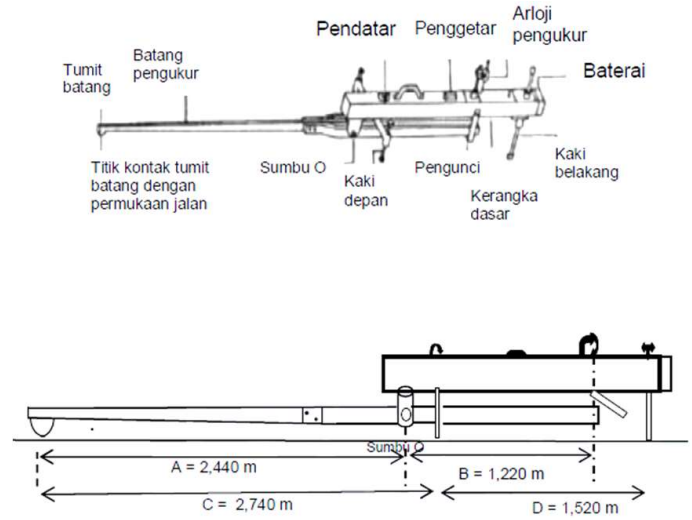

Gambar 4. Sketsa Pengujian alat BB

\subsection{Prosedur Pengolahan Data}

Berdasarkan kedua alat yang digunakan untuk mendapatkan nilai lendutan, maka data dicatat dan dicari nilai koreksi lendutan lapangan. Nilai lendutan menggunakan persamaan lendutan langsung.

Untuk perencanaan dengan alat $\mathrm{BB}$, dicatat nilai temperatur lapis beraspal $\left(T_{L}\right)$ dan faktor penyesuaian lendutan terhadap temperatur standar $35^{\circ} \mathrm{C}\left(\mathrm{F}_{\mathrm{t}}\right)$, dan nilai faktor pengaruh muka air tanah $\left(\mathrm{C}_{\mathrm{a}}\right)$. Setelah itu diambil nilai faktor koreksi beban uji dan menghitung keseragaman lendutan. Selanjutnya, ditentukan lendutan balik $\left(\mathrm{d}_{\mathrm{B}}\right)$ berdasarkan persamaan lendutan balik.

Untuk perencanaan dengan alat FWD, dilakukan perhitungan jumlah lendutan balik dan kuadrat dari lendutan balik. Setelah itu, dilakukan perhitungan lendutan rata-rata dengan nilai deviasi standarnya.

Dari kedua hasil data lendutan, baik dengan alat FWD dan BB, dihitung tingkat keseragaman lendutannya. Dari perhitungan ini, kemudian dilanjutkan dengan perhitungan lendutan wakil ( $D_{\text {wakil }}$ atau $D_{\text {sbl ov }}$ ) dan lendutan rencana atau lendutan izin (Drencana atau $D_{\text {stl ov }}$ ).

Selanjutnya, dilakukan perhitungan tebal lapis tambah. Hasil tebal lapis tambah dikoreksi dengan faktor koreksi tebal lapis tambah $\left(F_{\circ}\right)$ dan dilanjutkan dengan perhitungan tebal lapis tambah terkoreksi $\left(\mathrm{H}_{\mathrm{t}}\right)$.

Hasil tersebut dipakai untuk nilai tebal lapis tambah yang digunakan. Dengan nilai tersebut, maka dapat ditentukan lapisan yang digunakan dengan faktor koreksi penyesuaian tebal lapis 
tambah (FK tambah dari kedua alat.

\section{Hasil dan Pembahasan}

Berdasarkan hasil yang diperoleh, maka dapat diketahui nilai lendutan terkoreksi dengan alat BB dan FWD. Data temperatur yang didapat dan digunakan untuk pengolahan disajikan ke dalam grafik temperatur untuk bagian lapisannya. Grafik yang disajikan adalah grafik temperatur permukaan lapis beraspal, grafik temperatur tengah lapis beraspal, dan grafik temperatur bawah lapis beraspal

Grafik temperatur permukaan lapis beraspal yang diperoleh di lapangan dapat dilihat pada gambar 5 .

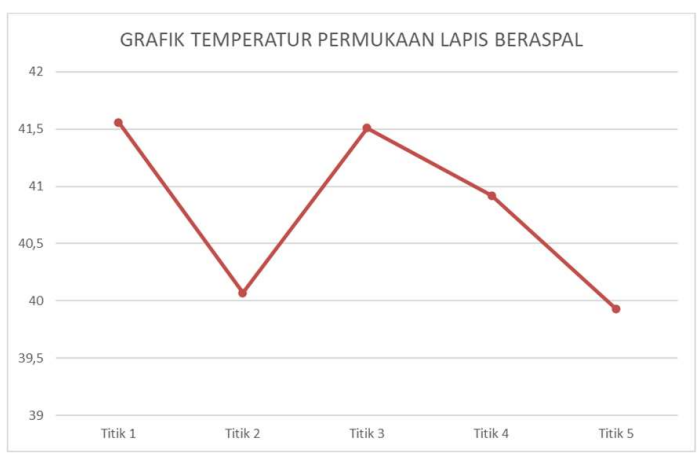

Gambar 5. Grafik Temperatur Permukaan Lapis Beraspal

Berdasarkan grafik temperatur permukaan lapis beraspal diperoleh data untuk 5 titik. Pada titik 1, temperatur permukaan lapis beraspal yang didapatkan adalah $41,56^{\circ} \mathrm{C}$. Pada titik 2 , temperatur permukaan lapis beraspal yang didapatkan adalah $40,07^{\circ} \mathrm{C}$. Pada titik 3, temperatur permukaan lapis beraspal yang diperoleh adalah $41,51^{\circ} \mathrm{C}$. Pada titik 4, temperatur permukaan lapis beraspal yang diperoleh adalah $40,92^{\circ} \mathrm{C}$. Sementara itu, pada titik 5, temperatur permukaan lapis beraspal yang diperoleh adalah $39,93^{\circ} \mathrm{C}$.

Grafik temperatur tengah lapis beraspal yang diperoleh di lapangan dapat dilihat pada gambar 6 .

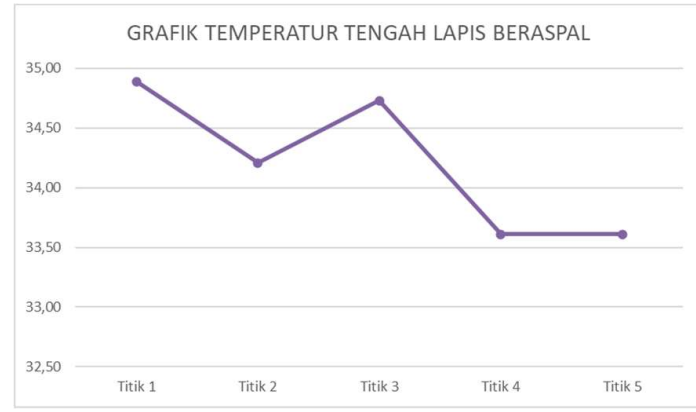

Gambar 6. Grafik Temperatur Tengah Lapis Beraspal

Berdasarkan grafik temperatur tengah lapis beraspal diperoleh data untuk 5 titik. Pada titik 1, temperatur tengah lapis beraspal yang didapatkan adalah $34,89^{\circ} \mathrm{C}$. Pada titik 2, temperatur tengah lapis beraspal yang didapatkan adalah $34,21^{\circ} \mathrm{C}$. Pada titik 3, temperatur tengah lapis beraspal yang diperoleh adalah $34,37^{\circ} \mathrm{C}$. Pada titik 4, temperatur tengah lapis beraspal yang diperoleh adalah $33,62^{\circ} \mathrm{C}$. Sementara itu, pada titik 5, temperatur tengah lapis beraspal yang diperoleh adalah $33,61^{\circ} \mathrm{C}$.

Grafik temperatur bawah lapis beraspal yang diperoleh di lapangan dapat dilihat pada gambar 7 .

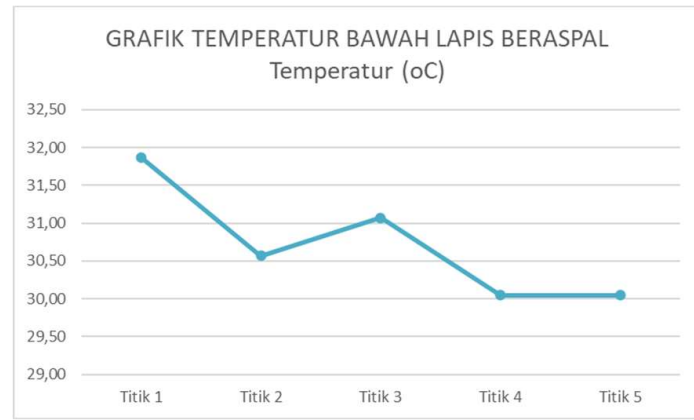

Gambar 7. Grafik Temperatur Bawah Lapis Beraspal

Berdasarkan grafik temperatur bawah lapis beraspal diperoleh data untuk 5 titik. Pada titik 1, temperatur bawah lapis beraspal yang didapatkan adalah $31,87^{\circ} \mathrm{C}$. Pada titik 2, temperatur bawah lapis beraspal yang didapatkan adalah $30,57^{\circ} \mathrm{C}$. Pada titik 3, temperatur bawah lapis beraspal yang diperoleh adalah $31,07^{\circ} \mathrm{C}$. Pada titik 4, temperatur bawah lapis beraspal yang diperoleh adalah $30,05^{\circ} \mathrm{C}$. Sementara itu, pada 
titik 5, temperatur bawah lapis beraspal yang diperoleh adalah $30,05^{\circ} \mathrm{C}$.

Setelah diperoleh data temperatur permukaan lapis beraspal, data temperatur tengah lapis beraspal, dan data temperatur bawah lapis beraspal, maka dapat diperoleh temperatur lapis beraspal berdasarkan nilai dari rata-rata temperatur permukaan lapis permukaan, temperatur tengah lapis beraspal, dan temperatur bawah lapis beraspal. Data ini diperoleh pada masing-masing titik pengambilan. Grafik nilai temperatur lapis beraspal dapat dilihat pada gambar 8 .

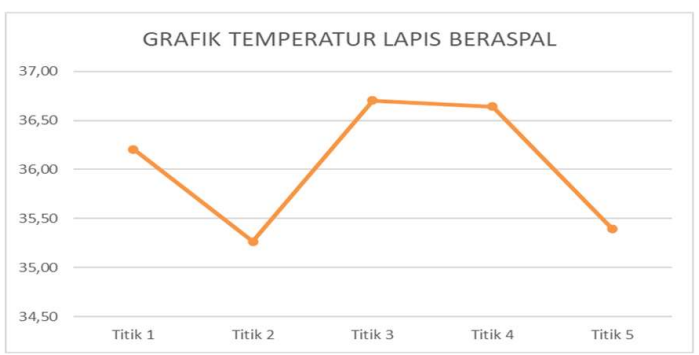

Gambar 8. Grafik Temperatur Lapis Beraspal

Berdasarkan grafik temperatur lapis beraspal diperoleh data untuk 5 titik. Pada titik 1, temperatur lapis beraspal yang didapatkan adalah $36,21^{\circ} \mathrm{C}$. Pada titik 2, temperatur lapis beraspal yang didapatkan adalah $35,27^{\circ} \mathrm{C}$. Pada titik 3, temperatur lapis beraspal yang diperoleh adalah $36,70^{\circ} \mathrm{C}$. Pada titik 4, temperatur lapis beraspal yang diperoleh adalah $36,64^{\circ} \mathrm{C}$. Sementara itu, pada titik 5 , temperatur lapis beraspal yang diperoleh adalah $35,40^{\circ} \mathrm{C}$.

Setelah masing-masing titik pengambilan memperoleh temperatur lapis beraspal, maka didapatkan nilai faktor penyesuaian lendutan $\left(F_{t}\right)$ terhadap nilai temperatur standar yang telah ditetapkan, yaitu pada temperatur $35^{\circ} \mathrm{C}$. Grafik koreksi pada temperatur standar dapat dilihat pada gambar 9.

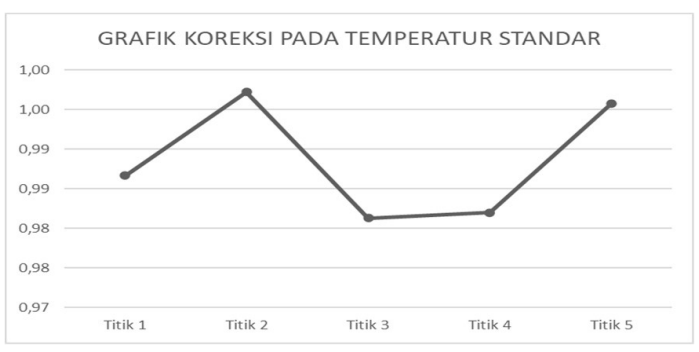

Gambar 9. Grafik Koreksi pada Temperatur Standar
Berdasarkan grafik koreksi pada temperatur standar diperoleh data untuk 5 titik. Pada titik 1, koreksi pada temperatur standar yang didapatkan adalah $0,9^{\circ} \mathrm{C}$. Pada titik 2, koreksi pada temperatur standar yang didapatkan adalah $1,00^{\circ} \mathrm{C}$. Pada titik 3 , koreksi pada temperatur standar yang diperoleh adalah $0,98^{\circ} \mathrm{C}$. Pada titik 4, koreksi pada temperatur standar yang diperoleh adalah $0,98^{\circ} \mathrm{C}$. Sementara itu, pada titik 5, koreksi pada temperatur standar yang diperoleh adalah $1,00^{\circ} \mathrm{C}$. Nilai koreksi tertinggi diperoleh pada titik 2 , yaitu sebesar $1,00^{\circ} \mathrm{C}$. Untuk nilai koreksi terendah diperoleh pada titik 3 dan titik 4, yaitu $0,98^{\circ} \mathrm{C}$.

Data temperatur lapis beraspal dan koreksi pada temperatur standar yang telah didapatkan ini digunakan dalam penentuan tebal overlay, baik dengan alat FWD maupun BB. Nilai koreksi yang digunakan pada kajian ini adalah 1,2

\subsection{Hasil Penentuan Tebal Overlay dengan alat FWD}

Pada penentuan tebal overlay dengan alat FWD, ditentukan lendutan langsung pada pusat beban. Grafik lendutan langsung pada pusat beban dapat dilihat pada gambar 10. Pada gambar 10 , diperoleh nilai lendutan langsung pada pusat beban untuk 5 titik.

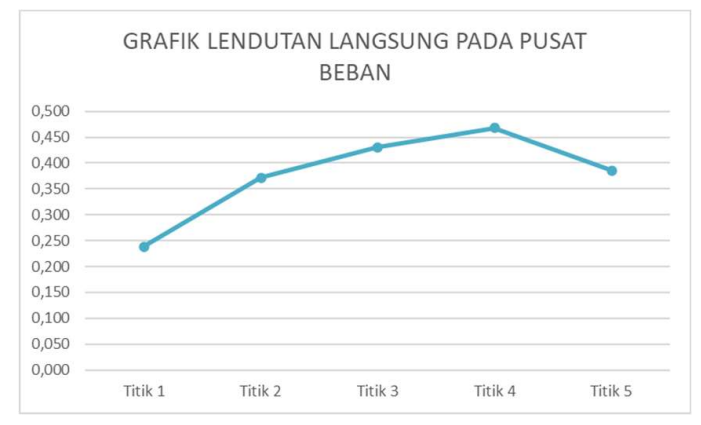

Gambar 10. Grafik Lendutan Langsung pada Pusat Beban (mm)

Berdasarkan grafik lendutan langsung pada pusat beban diperoleh data untuk 5 titik. Pada titik 1, lendutan langsung yang didapatkan adalah 0,238 mm. Pada titik 2, lendutan langsung yang didapatkan adalah $0,372 \mathrm{~mm}$. Pada titik 3, lendutan langsung yang diperoleh adalah $430 \mathrm{~mm}$. Pada titik 4, lendutan langsung yang diperoleh adalah $0,468 \mathrm{~mm}$. Sementara 
itu, pada titik 5, lendutan langsung yang diperoleh adalah $0,385 \mathrm{~mm}$.

Pada perhitungan lendutan terkoreksi, digunakan nilai koreksi beban sebesar 0,498. Dengan data lendutan langsung pada pusat beban, koreksi pada temperatur standar, koreksi musim, dan koreksi beban, maka didapat lendutan sebelum overlay. Penentuan ini berdasarkan persamaan 3 .

Berdasarkan hasil perhitungan, grafik lendutan sebelum overlay, dapat dilihat pada gambar 11 .

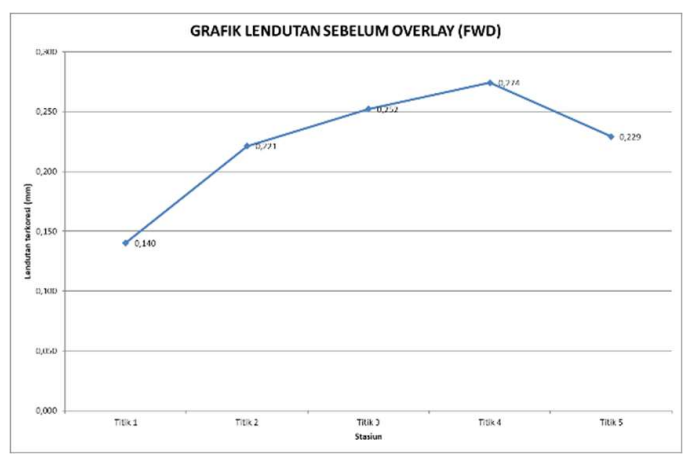

Gambar 11. Grafik Lendutan Sebelum Overlay dengan Alat FWD

Berdasarkan grafik lendutan sebelum overlay dengan alat FWD, diperoleh data untuk 5 titik. Pada titik 1, lendutan terkoreksi yang didapatkan adalah $0,140 \mathrm{~mm}$. Pada titik 2, lendutan terkoreksi yang didapatkan adalah $0,221 \mathrm{~mm}$. Pada titik 3, lendutan terkoreksi yang diperoleh adalah 0,252 mm. Pada titik 4, lendutan terkoreksi yang diperoleh adalah 0,274 . Sementara itu, pada titik 5 , lendutan terkoreksi yang diperoleh adalah 0,229 mm.

Dari nilai lendutan terkoreksi tersebut, maka nilai kuadratnya dapat dilihat pada tabel 1 .

Tabel 1. Kuadrat nilai lendutan terkoreksi alat FWD

\begin{tabular}{cc}
\hline Lokasi & $\mathrm{dL}^{2}$ \\
\hline Titik 1 & 0,020 \\
Titik 2 & 0,049 \\
Titik 3 & 0,064 \\
Titik 4 & 0,075 \\
Titik 5 & 0,052 \\
\hline
\end{tabular}

Jumlah total nilai lendutan langsung pada pusat beban untuk semua titik adalah 1,117 mm. Untuk nilai total kuadrat dari nilai lendutannya adalah sebesar 0,260 $\mathrm{mm}$. Lendutan rata-rata yang diperoleh untuk alat FWD adalah 0,223 $\mathrm{mm}$ dengan standar deviasi sebesar 0,051.

Setelah diperoleh nilai lendutan terkoreksi dengan alat FWD, maka diperoleh nilai faktor keseragaman (FK), lendutan wakil $D_{s b l}$ ov, lendutan rencana $D_{\text {stl ov }}$, tebal lapis tambah yang digunakan $\left(\mathrm{H}_{\mathrm{o}}\right)$, faktor koreksi tebal lapis tambah $\left(F_{\circ}\right)$, dan tebal lapis tambah terkoreksi $\left(\mathrm{H}_{\mathrm{t}}\right)$. Hasil ini dapat dilihat pada tabel 2.

Tabel 2. Hasil penentuan tebal overlay (alat FWD)

\begin{tabular}{cc}
\hline$F K(\%)$ & 22,825 \\
\hline$D_{\text {sbl ov }}(\mathrm{mm})$ & 0,325 \\
$D_{\text {stl ov }}(\mathrm{mm})$ & 0,246 \\
$H_{\circ}(\mathrm{cm})$ & 5,225 \\
$F_{\circ}$ & 1,002 \\
$H_{t}(\mathrm{~cm})$ & 5,235 \\
\hline
\end{tabular}

Nilai faktor keseragaman dengan menggunakan alat FWD adalah 22,825\%. Nilai ini berada pada rentang 21 sampai dengan 30 , yang berarti keseragaman lendutannya berada pada kategori cukup baik. Dari hasil perhitungan penentuan tebal overlay dengan alat FWD, diperoleh tebal $5,235 \mathrm{~cm}$. Hasil tebal ini dibulatkan menjadi $6 \mathrm{~cm}$.

\subsection{Hasil Penentuan Tebal dengan alat BB}

Berdasarkan alat BB, diperoleh nilai lendutan balik pada waktu beban tepat berada di titik pengukuran $\left(d_{1}\right)$ dan lendutan ketika beban sedang berada sejauh 6 meter dari titik pengambilan data lendutan balik $\left(d_{3}\right)$ hasil nilai lendutan balik $\mathrm{d}_{1}$ dan $\mathrm{d}_{3}$ dapat dilihat pada gambar 12 .

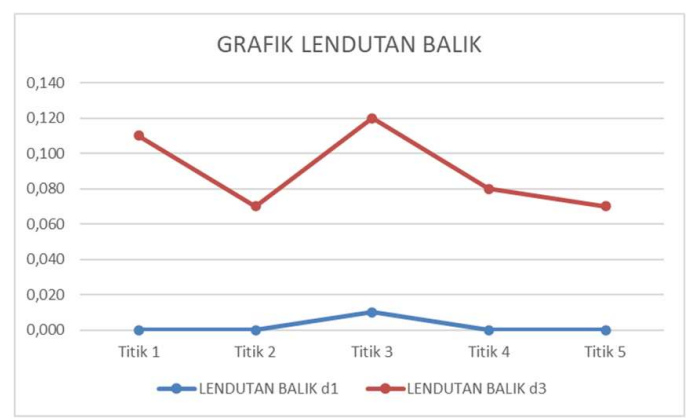

Gambar 12. Grafik Lendutan balik $d_{1}$ dan $d_{3}$ dengan Alat FWD 
Nilai lendutan balik $d_{1}$ dan $d_{3}$ digunakan pada penentuan nilai lendutan sebelum overlay $\left(\mathrm{d}_{\mathrm{B}}\right)$. Berdasarkan persamaan 1. Hasil grafik lendutan sebelum overlay, dapat dilihat pada Gambar 13

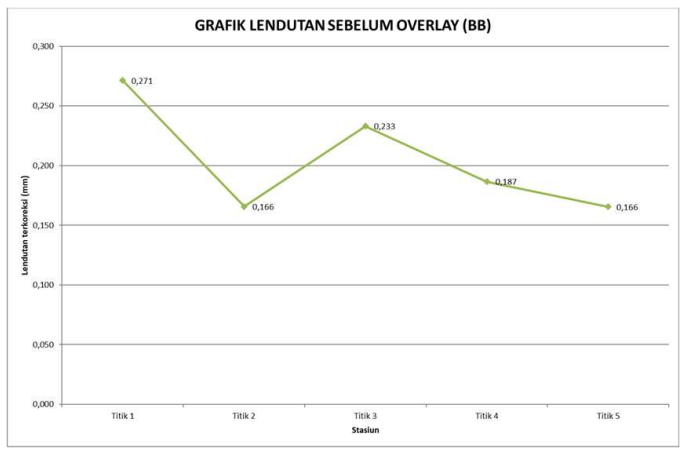

Gambar 13. Grafik Lendutan Sebelum Overlay dengan Alat BB

Berdasarkan grafik lendutan sebelum overlay dengan alat $\mathrm{BB}$, diperoleh data untuk 5 titik. Pada titik 1, lendutan terkoreksi yang didapatkan adalah $0,271 \mathrm{~mm}$. Pada titik 2, lendutan terkoreksi yang didapatkan adalah $0,166 \mathrm{~mm}$. Pada titik 3, lendutan terkoreksi yang diperoleh adalah $0,233 \mathrm{~mm}$. Pada titik 4 , lendutan terkoreksi yang diperoleh adalah 0,187 . Sementara itu, pada titik 5 , lendutan terkoreksi yang diperoleh adalah $0,166 \mathrm{~mm}$. Nilai lendutan terkoreksi tertinggi pada hasil ini berada pada titik 1 dengan nilai lendutan sebesar $0,271 \mathrm{~mm}$. Nilai lendutan terkoreksi terendah pada hasil ini berada pada titik 2 dan titik 5 dengan nilai sebesar $0,166 \mathrm{~mm}$.

Dari nilai lendutan terkoreksi tersebut, maka nilai kuadratnya dapat dilihat pada tabel 3 .

Tabel 3. Kuadrat nilai lendutan terkoreksi

\begin{tabular}{cc}
\multicolumn{2}{c}{ alat FWD } \\
\hline Lokasi & $\mathrm{dL}^{2}$ \\
\hline Titik 1 & 0,074 \\
Titik 2 & 0,027 \\
Titik 3 & 0,054 \\
Titik 4 & 0,035 \\
Titik 5 & 0,027 \\
\hline
\end{tabular}

Jumlah total nilai lendutan langsung pada pusat beban untuk semua titik adalah 1,022 mm. Untuk nilai total kuadrat dari nilai lendutannya adalah sebesar $0,218 \mathrm{~mm}$. Lendutan rata-rata yang diperoleh untuk alat $\mathrm{BB}$ adalah $0,204 \mathrm{~mm}$ dengan standar deviasi sebesar 0,046.

Setelah diperoleh nilai lendutan terkoreksi dengan alat BB, maka diperoleh hasil penentuan tebal overlay yang terdiri dari nilai faktor keseragaman (FK), lendutan wakil $D_{\text {sbl ov, }}$ lendutan rencana $D_{\text {stl }}$ ov, tebal lapis tambah yang digunakan $\left(\mathrm{H}_{\mathrm{o}}\right)$, faktor koreksi tebal lapis tambah $\left(\mathrm{F}_{\mathrm{o}}\right)$, dan tebal lapis tambah terkoreksi $\left(\mathrm{H}_{\mathrm{t}}\right)$. Hasil ini dapat dilihat pada tabel 4.

Tabel 4. Hasil penentuan tebal overlay (alat BB)

\begin{tabular}{cc}
\hline FK (\%) & 22,745 \\
\hline$D_{\text {sbl ov }}(\mathrm{mm})$ & 0,297 \\
$D_{\text {stl ov }}(\mathrm{mm})$ & 0,246 \\
$H_{\circ}(\mathrm{cm})$ & 3,715 \\
$F_{\circ}$ & 1,002 \\
$H_{t}(\mathrm{~cm})$ & 3,722 \\
\hline
\end{tabular}

Nilai faktor keseragaman dengan menggunakan alat FWD adalah $22,745 \%$. Nilai ini berada pada rentang 21 sampai dengan 30 , yang berarti keseragaman lendutannya berada pada kategori cukup baik. Dari hasil perhitungan penentuan tebal overlay dengan alat BB, diperoleh tebal $3,722 \mathrm{~cm}$. Hasil tebal ini dapat dibulatkan menjadi $4 \mathrm{~cm}$.

Dari hasil kajian sebelumnya yang telah dipaparkan, dapat dilihat adanya perbedaan hasil perencanaan tebal overlay antara alat FWD dan BB. Perbedaan kedua hasil ini dapat dilihat seperti pada tabel 5 .

Tabel 5. Perbedaan hasil penentuan tebal overlay dengan FWD dan alat BB

\begin{tabular}{ccccc}
\hline Hasil & FWD & BB & Selisih & $\%$ \\
\hline FK $(\%)$ & 22,825 & 22,745 & 0,080 & 0,35 \\
Dsbl ov $_{(\mathrm{mm})}$ & 0,325 & 0,297 & 0,028 & 8,62 \\
Dstl ov $_{(\mathrm{mm})}$ & 0,246 & 0,246 & 0,000 & 0,00 \\
$\mathrm{H}_{\mathrm{o}}(\mathrm{cm})$ & 5,225 & 3,715 & 1,510 & 28,90 \\
$\mathrm{~F}_{\circ}$ & 1,002 & 1,002 & 0,000 & 0,00 \\
$\mathrm{H}_{\mathrm{t}}(\mathrm{cm})$ & 5,235 & 3,722 & 1,513 & 28,90 \\
\hline
\end{tabular}

Dari kedua hasil tersebut, dapat dilihat bahwa untuk hasil faktor keseragaman, baik alat FWD dengan nilai FK 22,825\%, maupun alat BB dengan nilai FK 22,745 berada pada rentang 
antara $21 \%$ sampai dengan $30 \%$. Pada rentang ini, keseragaman lendutan keduanya masih cukup baik. Walaupun berada pada rentang yang sama, terdapat selisih keduanya dengan selisih 0,080 atau persentase selisihnya sangat kecil, yaitu $0,35 \%$.

Untuk hasil lendutan wakil ( $D_{\text {sbl ov }}$ ), nilai yang diperoleh pada alat FWD adalah $0,325 \mathrm{~mm}$ dan nilai yang diperoleh pada alat BB adalah 0,297 $\mathrm{mm}$. Selisih hasil keduanya adalah $0,028 \mathrm{~mm}$, atau persentase selisihnya adalah $8,62 \%$.

Untuk hasil lendutan rencana $\left(D_{\text {st ov }}\right)$, nilai yang diperoleh pada alat FWD adalah 0,246 mm dan nilai yang diperoleh pada alat BB adalah 0,246 $\mathrm{mm}$. Dikarenakan nilai yang diperoleh pada hasil ini sama, maka tidak ada selisih hasil di antara keduanya, sehingga persentase selisihnya adalah $0,00 \%$.

Tebal lapis tambah $\left(\mathrm{H}_{\circ}\right)$ dari kedua alat menghasilkan selisih yang signifikan. Untuk hasil dengan menggunakan alat FWD, nilai lapis tambah yang diperoleh adalah $5,255 \mathrm{~mm}$, sementara hasil dengan menggunakan alat BB adalah $3,715 \mathrm{~mm}$. Perbedaan keduanya menghasilkan selisih sebesar $1,510 \mathrm{~mm}$, atau dalam bentuk persen selisihnya adalah sebesar 28,90 . Secara persentase, selisih ini merupakan selisih terbesar dibandingkan dengan selisih untuk hasil yang lain.

Hasil perhitungan faktor koreksi tebal lapis tambah $\left(F_{\circ}\right)$ untuk alat FWD adalah 1,002. Untuk hasil perhitungan faktor koreksi tebal lapis tambah untuk alat BB memiliki nilai yang sama, yaitu 1,002. Dengan demikian, tidak terdapat selisih hasil yang signifikan, sehingga persentase selisinnya adalah $0,00 \%$.

Pada hasil penentuan tebal lapis tambah terkoreksi $\left(\mathrm{H}_{\mathrm{t}}\right)$, untuk hasil dengan alat FWD menghasilkan tebal sebesar $5,235 \mathrm{~cm}$, sedangkan hasil dengan alat BB berbeda. Untuk hasil penentuan tebal lapis tambah terkoreksi dengan alat $\mathrm{BB}$ adalah $3,722 \mathrm{~cm}$. Kedua perbedaan ini menghasilkan selisih sebesar $1,513 \mathrm{~cm}$, atau dalam bentuk persentase sebesar $28,90 \%$.

Tebal overlay yang direncanakan pada ruas jalan ditentukan sesuai dengan Pd T-05-2005, untuk melayani lalu lintas dengan umur rencana selama 10 tahun. Perkerasan yang digunakan pada perencanaan untuk kedua alat adalah perkerasan lapisan aspal beton (laston). Lapisan ini menggunakan nilai faktor koreksi penyesuaian sebesar 1,00 . Untuk nilai modulus resilien yang digunakan adalah untuk 2.000 $\mathrm{MPa}$. Nilai stabilitas Marshall minimun yang digunakan adalah $800 \mathrm{~kg}$.

Pada akhir perhitungan tebal overlay ini, didapat hasil bahwa penentuan tebal overlay dengan menggunakan alat FWD akan menjadi lebih besar dibandingkan dengan menggunakan alat BB. Dengan demikian, secara ekonomis hasil perencanaan tebal overlay yang memperoleh nilai ketebalan yang lebih tinggi akan akan menghasilkan biaya yang lebih besar dibandingkan dengan hasil yang lebih kecil, namun akan menghasilkan konstruksi yang lebih kuat. Sebaliknya, untuk hasil tebal overlay yang lebih kecil akan berimbas kepada biaya yang lebih hemat, namun secara konstruksi akan menjadi lebih lemah.

\subsection{Hasil Penelitian Sebelumnya}

Hasil perencanaan tebal overlay dalam kajian Wahyudi dkk. [12] menghasilkan bahwa metode perencanaan dengan menggunakan lendutan balik (alat BB) menghasilkan nilai yang lebih ekonomis jika dibandingkan dengan hasil perencanaan tebal overlay yang diperoleh dari pedoman interim No. 002/P/BM/2011.

Pada kajian yang dilaksanakan oleh Wicaksono dkk. [6], didapat bahwa dengan menggunakan metode Pd T-05-2005, diperoleh hasil bahwa nilai yang diperoleh nilai tebal lapis tambah yang lebih besar dibandingkan dengan metode SDPJL.

Sementara itu, hasil kajian yang dibuat oleh Pangerapan dkk. [13] memperoleh nilai yang lebih kecil antara metode Pd T-05-2005 dengan Manual Desain Perkerasan Jalan 2013.

Dengan demikian, baik hasil perencanaan tebal overlay yang menggunakan alat FWD dan BB masih berupa nilai tebal perkerasan yang terkecil. Hal ini dikarenakan oleh perencanaan tebal lapis tambah keduanya menggunakan metode Pd T-05-2005, walaupun keduanya dapat memberikan hasil yang berbeda. Dengan demikian hasil lapis tambah yang diperoleh akan menjadi lebih ekonomis, namun masih 
cukup untuk melayani beban lalu lintas rencana yang diterimanya.

\section{Kesimpulan}

Berdasarkan hasil pada kajian ini, dapat disimpulkan bahwa hasil penentuan tebal overlay dengan menggunakan alat FWD adalah 5,235 cm. Sementara itu, untuk hasil penentuan tebal overlay dengan menggunakan alat BB adalah $3,722 \mathrm{~cm}$. Kedua hasil perencanaan tebal overlay memiliki selisih sebesar $1,513 \mathrm{~cm}$, atau dalam bentuk persentase sebesar $28,90 \%$.

\section{Daftar Pustaka}

[1] Giovani dan Mukhlis, A., 2019. Analisis Struktur Pengaruh Beban Aksial Terhadap Balok, Jurnal Geuthèë: Penelitian Multidisiplin, Volume 2 Nomor 2 (Mei 2019), pp. 119-130.

[2] Emersleben. A., dan Meyer, N., 2008. The Use of Geocells in Road Constructions Over Soft Soil: Vertical Stress and Falling Weight Deflectometer Measurements. Proceedings of $4^{\text {th }}$ European Geosynthetics Conference, Edinburgh, UK, pp. 1-8.

[3] Badan Standardisasi Nasional (BSN), 2011. Cara Uji Lendutan Perkerasan Lentur Dengan Alat Benkelman Beam (SNI 2416:2011), Jakarta: BSN.

[4] Direktorat Jenderal Bina Marga, 2017. Pedoman Konstruksi dan Bangunan: Perencanaan Tebal Lapis Tambah Perkerasan Lentur dengan Metoda Lendutan (Revisi Juni 2017) Nomor 04/SE/Db/2017, Departemen Pekerjaan Umum.

[5] Primusz. P., 2015. Effect of Pavement Stiffness on the Shape of Deflection Bowl, Acta Silv. Lign. Hung. 11 (1), pp 39-54.

[6] Wicaksono, A.N., 2017. Perencanaan Tebal Lapis Tambah Metode PD T-052005-B dan Metode SDPJL pada Jalan Nasional di Yogyakarta, e-Jurnal MATRIKS TEKNIK SIPIL, Volume 4 Nomor 4 Tahun 2015, pp. 623-631.

[7] Suriyatno, 2014. Analisis Tebal Lapis Tambah dan Umur Sisa Perkerasan Akibat Beban Berlebih Kendaraan (Studi Kasus Ruas Jalan Nasional di Provinsi Sumatera Barat), Annual Civil Engineering Seminar, Pekanbaru. Pp. 169-176.

[8] Departemen Pekerjaan Umum, 2005. Pedoman Perencanaan Tebal Lapis Tambah Perkerasan Lentur dengan Metoda Lendutan (Pd T-05-2005-B).
[9] El-Hakim dan El-Ghaffar, 2020. General Procedure for Pavement Maintenance/Rehabilitation Decisions Based on Structural and Functional Indices, Proceedings of the 3rd GeoMEast International Congress and Exhibition, Egypt 2019 on Sustainable Civil Infrastructures - The Official International Congress of the Soil-Structure Interaction Group in Egypt (SSIGE), pp. 25-41.

[10] Aris, M.NA., 2015. Analisis Perbandingan Perencanaan Tebal Perkerasan Jalan Lentur menggunakan Beberapa Metode Bina Marga, Studi kasus: (Ruas Jalan Piringsurat-Batas Kedu Timur), Jurnal Karya Teknik Sipil Universitas Diponegoro, Volume 4 Nomor 4 Tahun 2015, pp. 380393.

[11] Dachlan, A.T., 2010. Metode Pelaksanaan dan Evaluasi Perbaikan Jalan Beton dengan Injeksi Semen, Cor di Tempat dan Beton Pracetak (Implementation and Evaluation Methods of Road Concrete Repair using Cement Injection, Cast in Place an Precast Concrete) Jurnal Pusjatan, Pusat Litbang Jalan dan Jembatan

[12] Wahudi, D, 2016. Analisis Perencanaan Tebal Lapis Tambah (overlay) Cara Lenduntan Balik Dengan Metode Pd T-052005-B dan Pedoman Interim No.002/P/BM/2011, JRSDD, Volume 4 Nomor 1, pp. 137-152.

[13] Pangerapan, M.L., 2018. Studi Perbandingan Perencanaan Tebal Lapis Tambah (Overlay) Perkerasan Lentur Menurut Metode Pd T-05-2005-B dan Manual Desain Perkerasan Jalan 2013 (Studi Kasus: Ruas Jalan Bts..Kota Manado - Tomohon), Jurnal Sipil Statik, Volume 6 Nomor 10, Pp. 823-834 